\title{
油脂過酸化物ことにサンマ油過酸化物
}

\author{
の分解について \\ 渡辺寿*外山修 之*
}

\section{Decomposition of Peroxides in Fats with a Particular \\ Reference to Those in Saury Oil}

Hisashi WATANABE and Yoshiyuki Toyama

\section{I. 緒言}

油脂の酸化飞際して過酸化物怯生成する一方飞和いて ある程度分解するから, 生成速度と分解速度の比率がわ からないかぎり油脂中に現存する過酸化物の量を測定し ても酸化によって生じた過酸化物の全量を知ることはで きない。したがって過酸化物の現存量を示寸過酸化物価 は油脂酸化の程度を示す確実な指標とみなすととはでき ないわけである。な和近来金田ら ${ }^{1), 21}$ ，松屋 ${ }^{3)}$ の研究に よって油脂過酸化物は強い毒性を示し, 酸化油脂中に現 存する過酸化物を分解すればその毒性は著しく軽減する ことが明らか、されたから, 油脂過酸化物の分解は油脂 栄養価の点からみても実際上重要な問題である。

油脂過酸化物飞関しては非常飞多くの研究が発表され ているが，そのうち油脂過酸化物の分解関する研究は 比較的少ない上ろである。その扣るなるのを挙げると， 中村) はす寸で 1937 年飞大豆油その他二, 三の植物油 そついてとの過酸化物の熱分解速度ならびにとれに対す る乾燥剤（アビエチン酸マンガン，アマ二油酸鉛）, 酸 化防止肪(ヒドロキノン, ナフトールなど), 固体微粉末 （酸性白土，活性炭，ケイソウ土）添加の影響をかなり 詳細と研究した。Holman ${ }^{5}$ とよるとりノール酸メチル のヒドロパーオキシドは $80^{\circ} \mathrm{C}$ で每時 $1.6 \%$ の割合で分 解し, Privett, Lundberg ${ }^{6}$ とよるとリノール酸メチル

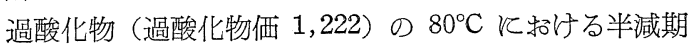
は $28 \mathrm{hr}$ である。また Lundberg ${ }^{7)}$ とるとリノール酸 メチル過酸化物の分解反応は過酸化物が低濃度の場合は 一次反応, 高濃度の場合飞は二次反応飞従う。Privett, Quackenbush $^{8)}$ は豚脂過酸化物の $100^{\circ} \mathrm{C}$ 真空加熱仗よ' る分解浪いて抗酸化剂 ( ヒドロキノン) の添加㤋分解を促進しっクエン酸,アスコ ルビン酸はとれ自体では影響しないが上記抗酸化剤の 分解促進作用をある程度抑制することを認めた。最近 Cooney $5^{9)}$ は過酸化物価 98 の大豆油を $100^{\circ} \mathrm{C}, 150^{\circ} \mathrm{C}$,

* 名古屋大学工学部応用化学教室 (名古屋市千種区不 老町) Department of Applied Chemistry, Faculty of Engineering, Nagoya University $180^{\circ} \mathrm{C}$ で加熱した場合の過酸化物の分解率を測定した。 それ飞よると $100^{\circ} \mathrm{C}$ 飞扣ける分解率は加熱時間と直線 関係を示し毎時 $6 \%$ の割合である。

上記の文献はいずれる植物油またはそ成分脂肪酸か. 豚脂の過酸化物の分解に関するもので, 海産動物油中の 過酸化物の分解関しては詳しい研究が発表されていな い。魚干物を日常食卓飞供するわが国に执いては魚油中 の過酸化物の分解师関して知見を得ることば特に必要と 考光られるから, 著者は今回主としてサンマ油過酸化物 の分解について研究した。本研究ではまずサンマ油その 他数種の油脂飞ついて, その過酸化物の分解の難易を比 較した。またさきと下岡, 外山 ${ }^{10)}$ はサンマ油過酸化物が トゥモロコシ油過酸化物にくらべて分解しやすいことを 認めて, その原因はサンマ油中の高度不飽和酸が過酸化 物の分解際して酸素の受衝体として作用するのでない かと考光たが, 今回その当否を検討するためトウモロコ シ油その他の植物油とついて高度不飽和酸メチルエステ ルを添加した場合と添加しない場合の過酸化物の分解率 を比較してみた。つぎとサンマ油について, 異なる酸化 条件のもと飞生成した過酸化物の分解率を比較し, さら 飞過酸化物の分解率飞対する酸化促進剂, 抗酸化剂添加 の影響招よび日光照射の影響をしらべた。

\section{II. 実験およびその結果の考察}

\section{1. 諸種の油脂中の過酸化物の分解率およびそれに対 する高度不飽和酸メチルエステル添加の影響}

本実験飞用いた過酸化物価の高い油脂試料は 7 種 類 で, そのうちサンマ油, イワシ油, 鯨油, アマニ油は $50^{\circ} \mathrm{C}$ で空気吹込多によって酸化したるの, ゴマ油, トゥ モロコシ油, ツバキ油は室温で保存中に空気に触れて酸 化したものである。また添加試料として用いた高度不飽 和酸メチルエステル（ヨウ素価 373.8）はサンマ油から 製取したるのである。各試料油 $10 \mathrm{~g}$ を容量 $30 \mathrm{ml}$ の 試験管飞入れ，試験管を $100^{\circ} \mathrm{C}, 90^{\circ} \mathrm{C}, 50^{\circ} \mathrm{C}$ の油浴中に 置いて試験管内《窒素気流を通しながら所定時間加熱 乙,つぎに試験管を冷水中に移して急冷してから試料油 の過酸化物価を測定し加熱前の試料油の過酸化物偠と比 
表-1 諸種の油脂中の過酸化物の分解率ならびそ植物油過酸化物の分解率 ス及ぼす高度不飽和酸メチルエステル添加の影響

\begin{tabular}{|c|c|c|c|c|c|c|c|c|}
\hline \multirow{2}{*}{ 試 料 油 } & \multicolumn{2}{|c|}{$50^{\circ} \mathrm{C}$ 空気吹込及前の } & \multirow{2}{*}{$\mid \begin{array}{l}50^{\circ} \mathrm{C} \text { 空 } \\
\text { 気吹込 } \\
\text { 2時間 } \\
(\mathrm{hr})\end{array}$} & \multirow{2}{*}{$\begin{array}{l}\text { 実験開 } \\
\text { 始直前 } \\
\text { の過酸 } \\
\text { 化物価 }\end{array}$} & \multicolumn{2}{|c|}{ 分 } & \multicolumn{2}{|c|}{ 率 $\quad(\%)$} \\
\hline & $\begin{array}{c}\text { ヨウ素価 } \\
\text { (ウィイス法) }\end{array}$ & $\begin{array}{l}\text { 過酸化 } \\
\text { 物 価 }\end{array}$ & & & $100^{\circ} \mathrm{C}$ & $90^{\circ} \mathrm{C}$ & $50^{\circ} \mathrm{C}$ & \begin{tabular}{|cr} 
室 & 温 \\
$(140$ 日間
\end{tabular} \\
\hline サンマ油 & 156.9 & 7.0 & 31 & 280 & $\begin{array}{c}67 \\
(2 \mathrm{hr})\end{array}$ & $\begin{array}{l}46 \\
(1.75 \mathrm{hr})\end{array}$ & $\begin{array}{c}31 \\
(4 \mathrm{hr})\end{array}$ & 90 \\
\hline イワシ油 & 166.0 & 5.0 & 31 & 184 & $\begin{array}{l}56 \\
(2 \mathrm{hr})\end{array}$ & $\begin{array}{c}45 \\
(1.75 \mathrm{hr})\end{array}$ & $\begin{array}{c}30 \\
(4 \mathrm{hr})\end{array}$ & - \\
\hline 鯨油 & 110.9 & 10.6 & 43 & 206 & - & $\begin{array}{c}29 \\
(1.75 \mathrm{hr})\end{array}$ & $\begin{array}{c}16 \\
(5 \mathrm{hr})\end{array}$ & 71 \\
\hline アマ二油 A & 186.2 & 1.8 & 43 & 179 & - & - & $\begin{array}{c}8.5 \\
(5 \mathrm{hr})\end{array}$ & - \\
\hline " $\mathrm{B}$ & - & - & - & - & - & - & $\begin{array}{c}9.6 \\
(5 \mathrm{hr})\end{array}$ & - \\
\hline ゴマ油 A & 94.2 & 140 & 0 & 140 & $\begin{array}{c}43 \\
(3 \mathrm{hr})\end{array}$ & - & - & 61 \\
\hline " $\mathrm{B}$ & - & - & - & - & $\begin{array}{l}45 \\
(3 \mathrm{hr})\end{array}$ & - & - & 61 \\
\hline $\begin{array}{l}\text { トウ モロコ } \\
\text { シ油 }\end{array}$ & 124.7 & 141 & 0 & 141 & $\begin{array}{c}7.6 \\
(3 \mathrm{hr})\end{array}$ & - & - & 5.7 \\
\hline " B & - & - & - & - & $\begin{array}{c}18 \\
(3 \mathrm{hr})\end{array}$ & - & - & 9.2 \\
\hline ツバキ油 A & 78.2 & 147 & 0 & 147 & $\begin{array}{c}15 \\
(3 \mathrm{hr})\end{array}$ & - & $\begin{array}{c}3.0 \\
(4 \mathrm{hr})\end{array}$ & 36 \\
\hline " & - & - & - & - & $\begin{array}{c}19 \\
(3 \mathrm{hr})\end{array}$ & - & $\begin{array}{c}3.0 \\
(4 \mathrm{hr})\end{array}$ & 39 \\
\hline
\end{tabular}

備考 試料油のうち鯨油は硬化油製造用の精製油, トウモロコシ油は脱ロウサラダ油, その他は口過以外の精製工程を施さない未精製油である。サンマ油,イワシ油,鯨油, アマニ油は入手後, ブリキ缶または試薬ビンに入れて約 1 5 年間保存したすので ある。ゴマ油,トウモロコシ油, ツバキ油は入手後, 試薬ビンに入れて保存したるの であるが、ゴマ油とツバキ油は約 15 年間の保存中に空気に触れて著しく酸化し， トウモロコシ油も約 1 年間の保存中に酸化して，いずれも高い過酸化物価を示した から， $50^{\circ} \mathrm{C}$ 空気吹达みを行なわないでそのまま過酸化物分解実験の試料にした。
(アマニ油, ゴマ油, ト ウモロコジ油, ツバキ 油）の過酸化物の分解率 よりる大きいことがわか る。植物油飞高度不飽和 酸メチルエステルを添加 した場合には過酸化物の 分解率は括招导小増加の 傾向を示している。した がって, さきに下岡, 外 山 ${ }^{10)}$ が推定したように高 度不飽和酸《過酸化物か らの酸素の受働体として 低度不飽和酸よりるいく ぶえ活性に富み, 過酸化 物の分解率をある程度増 大するものと認められる が，その影響はとれはど 大きくないようである。 海産動物油の過酸化物の 分解率が大きい原因の一 つ惊高度不飽和酸の存在 にあると認められるが, そのほか、も大きい原因 があるのでないかと考光 られる。な捈表-1 のゴ マ油, トウモロコシ油,
較して過酸化物の分解率を求めた。また各植物油 $10 \mathrm{~g} V$ 高度不飽和酸メチルエステルを $10 \%$ 添加したものとつ いて無添加試料油と併列的飞実験を行ない，高度不飽和 酸メチルエステル中に少量含まれている過酸化物（過酸 化物価 15.5) の分解に対する補正を行なって各試料油中 の過酸化物の分解率を算出した。また別に各試料油 $20 \mathrm{~g}$ 扣よびこれル高度不飽和酸メチルエステルそ2 10\% 添加 したものを容量 $25 \mathrm{ml}$ のガラスビンに入れ，ビン内の 空気を窒素で置換してから密センしてカッ色デシケータ 一中に 140 日間保存し，過酸化物価を測定して保存中に 特ける各試料油の過酸化物の分解率を求めた。過酸化物 価（ミリ当量 $/ \mathrm{kg}$ ）の測定はWheeler 法に準じたが，試 料ヒョウ取量は $1 \mathrm{~g}$ とした。実験結果を示すと表-1の と招りである。表-1 の植物油の場合 $\mathrm{A}$ は無添加試料油, Bは高度不飽和酸メチルエステル $10 \%$ を添加したもの である。

表-1 の実験では全部の 陚料油にわたって同一の加熱 温度, 加熱時間に打ける過酸化物の分解率を測定しなか ったので, 各試料油の過酸化物の分解率を定量的に比較 することはできないが，大体に杼いて海産動物油（サン マ油, イワシ油, 鯨油) の過酸化物の分解率は植物油
ツバキ油の場合をみると，過酸化物の分解率はゴマ油が 最も大きく、ツバキ油がこれにつぎ，トウモロコシ油が 最も小さい。中村 ${ }^{4)}$ はキリ油, アマニ油, ツバキ油, ヒ マシ油についてキリ油過酸化物は熱に対して最も不安定 でツバキ油過酸化物は最も安定であることを認めた。こ のように植物油の種類によってその過酸化物の熱安定性 が違うことに対して種々の因子が考えられるが，本実験 の場合にはつぎのことが考学られる。すなわち 表-1 の ゴマ油, トウモロコシ油, ツバキ油はその過酸化物価が いずれも近接しているが，ゴマ油とツバキ油は約 15 年 保存中に酸化した試料で正常の陚料とくらべてそのヨウ 素価が低下し，また粘チョウ（稠）であったが，トウモ ロコシ油は約 1 年保存中に酸化した試料でとのヨウ素価 は正常の試料と大差なかった。したがって，これら試料 油は大体同じ程度に過酸化物を含むが，その酸化重合を 受けた程度は著しく違っていて，その違いが過酸化物の 分解に影響するのでないかと思われる。

\section{2. 異なる酸化条件のむとに生成したサンマ油過酸化 物の分解率}

前項の植物油の場合に述べたように, 酸化重合の程度 が極端に違うと過酸化物の分解率に影響するようである 
が，同一のサンマ油を多少異なる条件のもとと酸化して 生成した過酸化物についてその分解率を比較してみた。 供試サンマ油は $d_{4}^{30} 0.9137, n_{\mathrm{D}}^{30} 1.4705$, 酸価 5.0 , ケ ン化価 186.9, ヨウ素価 156.9 , 過酸化物価 7.0 の子の でこれをつぎのようにして酸化した。

(i) 油 $150 \mathrm{~g}$ を内径 $12 \mathrm{~cm}$ の結晶ザラに入れて木 コリが入らないようと結晶ザラをポリエチレンの膜で括 特い, 室内暗所飞置いて保存期間 8 17日で過酸化物価 50 付近䄈よび 150 付近の酸化油を収得した。

(ii）油を入れた結晶ザラを, ある時間直射日光に暴 露して保存期間 $1 \sim 2$ 日（直射日光暴露 $2 \sim 8 \mathrm{hr}$ ) で過 酸化物価 50 付近括よび 150 付近の酸化油を収得した。

（iii）油を $100^{\circ} \mathrm{C}$ 飞加熱し空気吹込みによって加熱 時間 $1 \sim 3 \mathrm{hr}$ で過酸化物価 50 付近衫よび 150 付近の酸 化油を収得した。

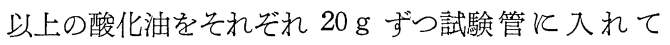
$125^{\circ} \mathrm{C}, 100^{\circ} \mathrm{C}, 75^{\circ} \mathrm{C}, 50^{\circ} \mathrm{C}$ の油浴中に置いて窒素気流を 送入しながら加熱し，所定時間経過したとき窒素圧を利

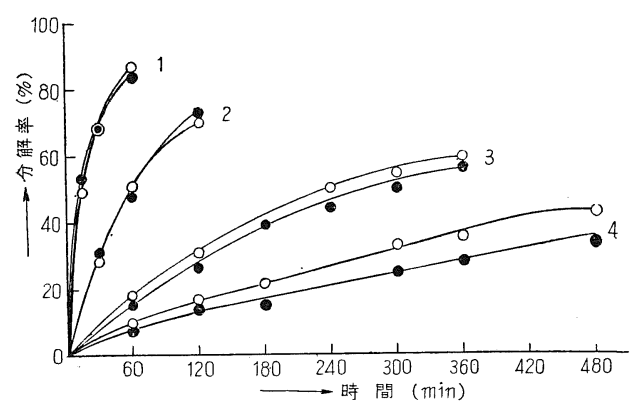

1. 分解温度 $125^{\circ} \mathrm{C}$

2. 分解温度 $100^{\circ} \mathrm{C}$

3. 分解温度 $75^{\circ} \mathrm{C}$

4. 分解温度 $50^{\circ} \mathrm{C}$

$\bigcirc$ 過酸化物価 50 付近の試料

- 過酸化物価 150 付近の試料

図-1 A 暗所保存飞よって生じたサンマ油過酸 化物の分解

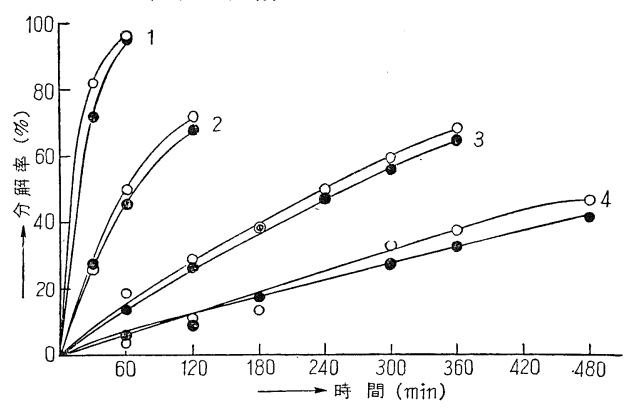

1. 分解温度 $125^{\circ} \mathrm{C} \quad 2$. 分解温度 $100^{\circ} \mathrm{C}$

2. 分解温度 $75^{\circ} \mathrm{C} \quad 4$. 分解温度 $50^{\circ} \mathrm{C}$

過酸化物価 50 付近の試料

- 過酸化物価 150 付近の試料

図-1B 日光暴露とよって生じたサンマ油過酸 化物の分解

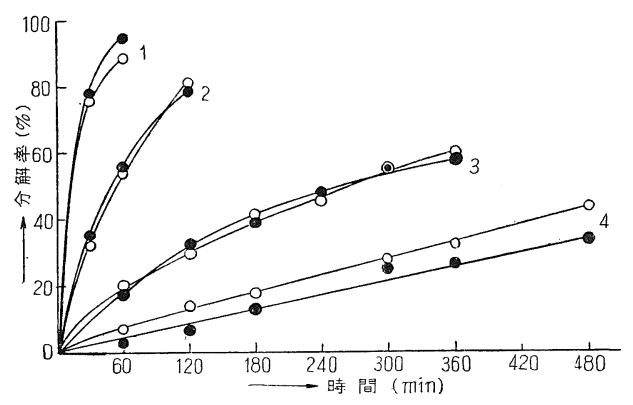

1. 分解温度 $125^{\circ} \mathrm{C} \quad 2$. 分解温度 $100^{\circ} \mathrm{C}$

3. 分解温度 $75^{\circ} \mathrm{C} \quad 4$. 分解温度 $50^{\circ} \mathrm{C}$

過酸化物価 50 付近の試料

- 過酸化物価 150 付近の試料

図-1 C $100^{\circ} \mathrm{C}$ 空気吹込及によって生じたサン 又油過酸化物の分解

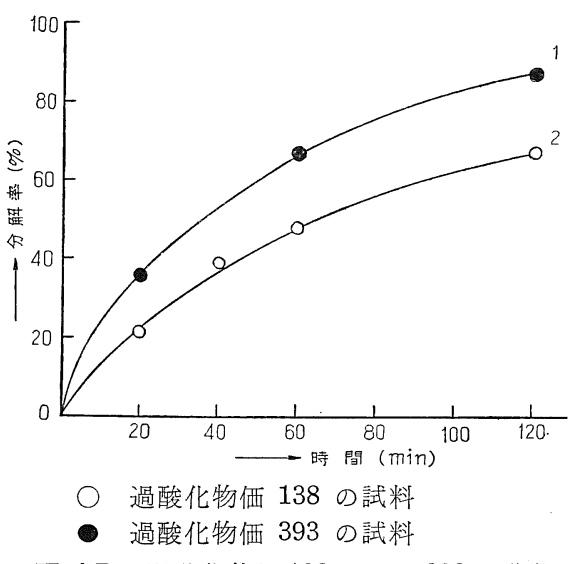

図-1D過酸化物価 138 および 393 の酸化サ ンマ油江打ける過酸化物の分解

用して油の一部をとり出して，その過酸化物価を測定し 過酸化物の分解率を求めた。実験結果を示すと 図-1 A,

$1 \mathrm{~B}, 1 \mathrm{C}$ のと招りである。

図-1 A, $1 \mathrm{~B}, 1 \mathrm{C}$ とよると $50^{\circ} \mathrm{C}$ 分解の場合飞過酸化 物価50付近の試料は過酸化物価 150 付近の試料よりも分 解率がやや大きい程度で, それ以外とは両試料の分解率 飞大差がない。また酸化条件の異なるサンマ油の過酸化 物の分解率は全然同じであるとはい党ないが, 前記酸化 条件の違いでは過酸化物の分解率飞著しい影響を及ぼさ ない上うである。乙かし, 別々 $100^{\circ} \mathrm{C}$ 空気吹込みによ。 て得た過酸化物価 138 のサンマ油と室温で長期保存して やや粘度の増大した過酸化物価 393 のサンマ油について $100^{\circ} \mathrm{C}$ 飞抢ける分解率を測定したところ 図-1 D 亿示し た結果を得た。すなわち室温長期保存によったサンマ油 では過酸化物の分解率が著しく大きい。このことは前項 できわめて長期間保存したゴマ油, ッバキ油の過酸化物 の分解率が大きいことと一致している。いずれにしても 本実験の結果によるとサンマ油過酸化物の分解率は前記 
Holman $^{5)}$, Privett, Lundberg ${ }^{6)}$ がリノール酸メチル過 酸化物について, Privett, Quackenbush ${ }^{8)}$ が豚脂過酸化 物について,Cooney $ら^{9}$ 氻大豆油過酸化物について発表 した分解率とくらべて格段に大きいことが注目される。

\section{3. 酸化促進剂および抗酸化剂がサンマ油過酸化物の}

\section{分解率に及ぼす影響}

油脂の酸化促進剤として知られている銅セッケン，鉄 セッケン，抗酸化浏と乙て使用される NDGA，BHA， PG がサンマ油過酸化物の分解にいかなる影響を及ぼす かをみるため, 酸化サンマ油にこれらの物質を添加した 場合と添加しない場合の過酸化物の分解率を比較した。 本実験に用いた酸化サンマ油は $100^{\circ} \mathrm{C}$ 空気吹込みによっ て得たるので，その過酸化物価は80 100であった。銅 セッケン招よび鉄セッケンはサンマ油脂肪酸のアンモニ ウム塩水溶液にとれぞれ硫酸銅招よび塩化第二鉄の水溶 液を加えて製取した。NDGA，BHA，PG は加熱しないと 酸化サンマ油に迅速に溶解しないから，あらかじめこれ らの抗酸化剤をエーテルを媒体としてサンマ油（過酸化 物価 1 以下）に溶かしエーテルを留去して抗酸化剤の濃

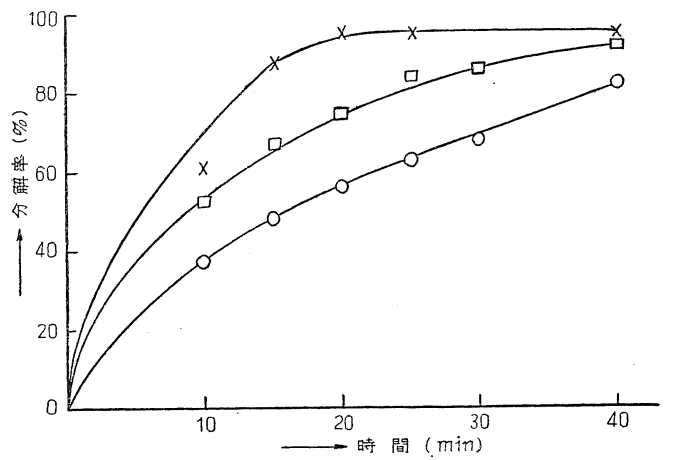

$\times$ 銅セッケン $0.2 \%$ 添加

$\square$ 鉄セッケン $0.2 \%$ 添加

$\bigcirc$ 無添加

図-2A サンマ油過酸化物の分解に及ぼす酸化 促進剂添加の影響 $\left(125^{\circ} \mathrm{C}\right.$ の場合 $)$

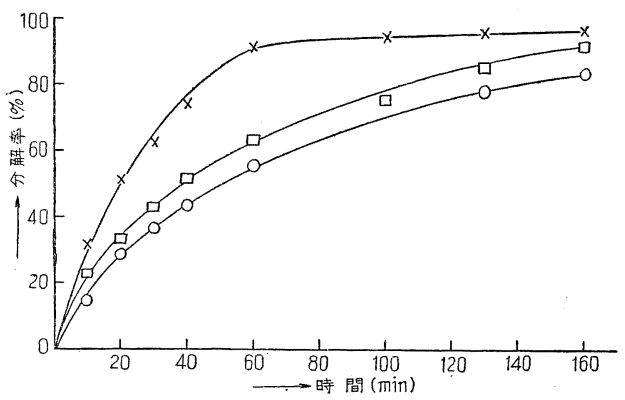

$\times$ 銅セッケン $0.2 \%$ 添加

$\square$ 鉄セッケン $0.2 \%$ 添加

無添加

図-2 B サンマ油過酸化物の分解に及ぼす酸化 促進剤添加の影響 $\left(100^{\circ} \mathrm{C}\right.$ の場合)
度の大きいサンマ油を調製し，このサンマ油の一定量を 供試酸化サンマ油に添加した。この場合の無添加対照実 験には供試酸化サンマ油に抗酸化剂を含まないサンマ油

（過酸化物価 1 以下）を同じ量だけ添加したものを用い た。実験結果は 図-2 A, 2 B , $2 \mathrm{C}, 3 \mathrm{~A}, 3 \mathrm{~B}, 4$ 飞示 した。

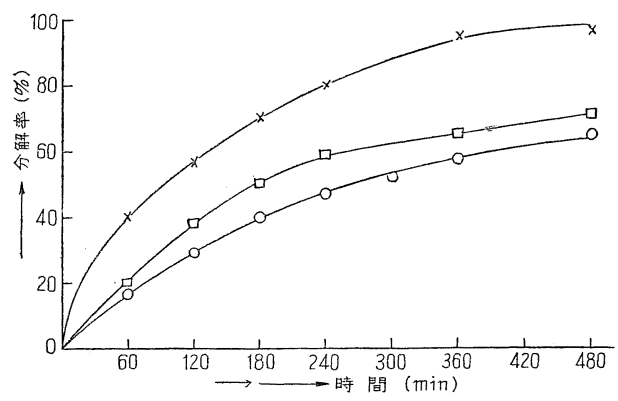

× 銅セッケン $0.2 \%$ 添加

$\square$ 鉄セッケン $0.2 \%$ 添加

無添加

図-2 C サンマ油過酸化物の分解に及ぼす酸化 促進剤添加の影響 $\left(\left(75^{\circ} \mathrm{C}\right.\right.$ の場合 $)$

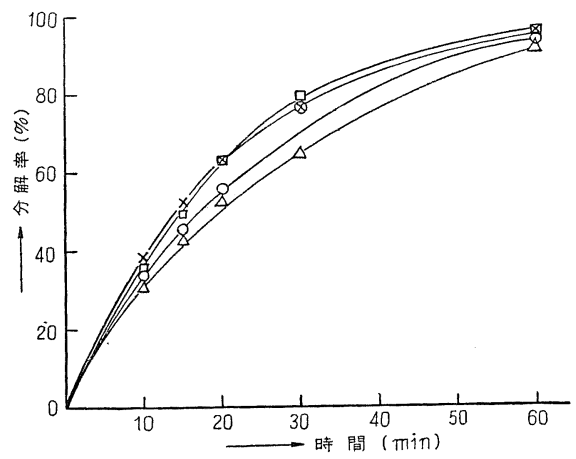

$\times$ NDGA $0.01 \%$ 添加 $\triangle \mathrm{PG} 0.01 \%$ 添加

$\square$ BHA 0.01\% 添加

図-3A サンマ油過酸化物の分解に及ぼす抗 酸化剂添加の影響 $\left(125^{\circ} \mathrm{C}\right.$ の場合)

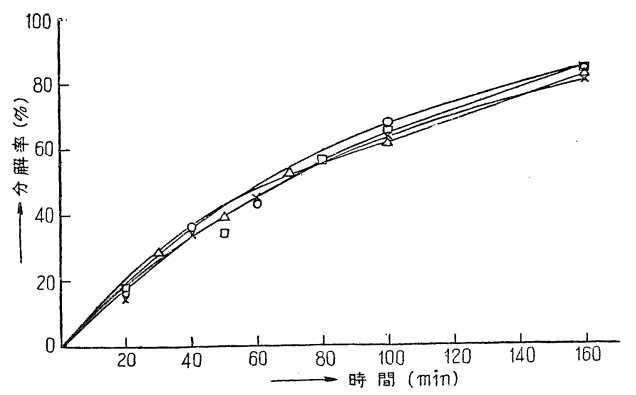

$\times$ NDGA $0.06 \%$ 添加

$\triangle \mathrm{PG} 0.04 \%$ 添加

$\square$ BHA 0.05\% 添加

無添加

図-3 B サンマ油過酸化物の分解に及ぼす抗酸 化剂添加の影響 $\left(100^{\circ} \mathrm{C}\right.$ の場合) 


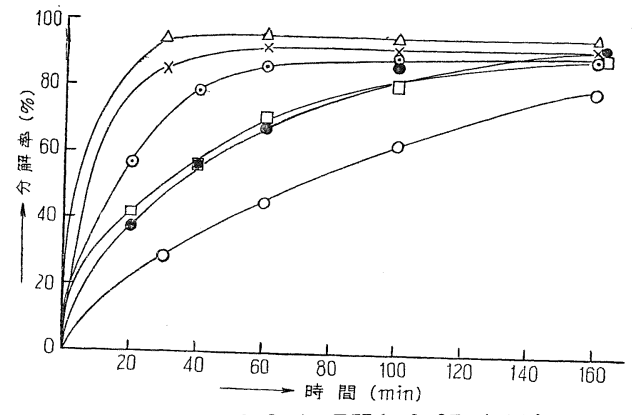

$\triangle$ 銅セッケン $0.2 \%$, BHA $0.05 \%$ 添加

$\times \quad$ 銅七ッケン $0.2 \%$ 添加

- 鉄セッケン $0.2 \%$, BHA $0.06 \%$ 添加

$\square$ 鉄セッケン $0.2 \%$ 添加

(๑)鉄セッケン $0.2 \%, \mathrm{PG} 0.07 \%$ 添加

無添加

図-4 サンマ油過酸化物の分解に及ぼす酸化促 進剂招よび抗酸化剂添加の影響

図-2 A，2 B， 2 C そよると銅セッケン, 鉄セッケン の添加（添加量 $0.2 \%$ ) はサンマ油過酸化物の分解を促 進し, 銅セッケンは鉄セッケンよりる促進作用が大き い。過酸化物の分解は $125^{\circ} \mathrm{C}$ の場合 (図-3A) PG 0.01 \%の添加によってわずか抑制されるようであるが, 抗酸 化剂添加の影響は明らかでない。銅セッケンや鉄セッケ ンなど酸化促進剤を添加した場合とくらべてその影響は はなはだ小さいと認められる。また酸化促進剤と抗酸化 剤を併用添加した場合は 図-4 とよると, 抗酸化剂を併 用乙て子酸化促進剂の過酸化物分解促進作用はほとんど 抑制されないようである。銅セッケンまたは鉄セッケン と NDGA をたは PG を併用添加すると, 試料油が著 しく暗色を呈し，金属セッケンと抗酸化剂との間に反応 が起るものと認められるが，これによって銅セッケンや 鉄セッケンの過酸化物分解促進作用はたいして影響を受 けないようである。

な招本実験に呿いて得たサンマ油過酸化物の分解反応 を一次反応末たは二次反応として反応速度恒数を求める と, 二次反応とした場合よりも一次反応とした場合の方 がばらつきが小さいが，乙かし一次反応として子多くの 場合相当大きなばらつきがあって過酸化物分解反応が全 面的水次応であるとみなすことはできない。図-3 A， $3 \mathbf{B}$ の実測值加 , 過酸化物分解率 $R(\%)$ と時間 $t$ (min) との関係を示扵正規方程式を求めるとつぎのと おりである。

加熱温度 $125^{\circ} \mathrm{C}$ の場合

銅セッケン $0.2 \%$ 添加

$\log R=(2.1 \pm 0.38)-(2.61 \pm 0.022) / t$

鉄七ッケン $0.2 \%$ 添加

$\log R=(2.1 \pm 0.06)-(3.46 \pm 0.004) / t$

無 添 加

$\log R=(2.0 \pm 0.27)-(3.86 \pm 0.024) / t$
加熱温度 $100^{\circ} \mathrm{C}$ の場合

銅セッケン $0.2 \%$ 添加 $\log R=(2.0 \pm 0.23)-(5.46 \pm 0.010) / t$

鉄セッケン $0.2 \%$ 添加

$\log R=(1.9 \pm 0.46)-(6.36 \pm 0.062) / t$

無 添 加

$\log R=(1.9 \pm 0.48)-(7.46 \pm 0.020) / t$

\section{4. 日光照射がサンマ油および大豆油の過酸化物の分 解に及ぼす影響}

日光照射が油脂の酸化を促進することはよく知られて いるが，下岡ら ${ }^{11)}$ の研究によるとサンマ油を空気吹込み によって酸化したものと日光照射のもとに酸化したもの と, 過酸化物価が同じ程度のものを比較すると日光照射 のもとに酸化したものは原武料油にくらべて, その性状 の変化が著しい。このことからみると, 日光照射は過酸 化物の生成を促進するととるにその分解を促進するもの と思われる。この点を確かめるためサンマ油执よ゙大豆 油について日光照射报よび遮光のもとに過酸化物の分解 率を比較した。実験に用いた酸化サンマ油拉よび酸化大 豆油は $100^{\circ} \mathrm{C}$ 空気吹込みによって得たるので, 各酸化 油試料を $2 \mathrm{~g}$ ずつ容量 $5 \mathrm{~m} l$ の無色透明ガラスビン拓よ びカッ色ガラスビンに入れビン内の空気を窒素で置換し てから密セッして保存し，保存期間中に一定時間直射日 光に暴露し, 一定期間後飞各試料油の過酸化物価を測定 した。その結果を示すと表-2 のと招りで, 無色ビンに 入れた試料油はカッ色ビンに入れて遮光した試料油より も過酸化物の分解率が大きい。

表-2 日光照射が過酸化物分解に及ぼす影響

\begin{tabular}{|c|c|c|c|c|c|c|c|}
\hline \multirow{3}{*}{$\begin{array}{l}\text { 経過 } \\
\text { 日数 } \\
\text { (日) }\end{array}$} & \multirow{3}{*}{$\left|\begin{array}{c}\text { 経過日 } \\
\text { 数中に } \\
\text { 日光照 } \\
\text { 射乙た } \\
\text { 時間 } \\
\text { (hr) }\end{array}\right|$} & \multicolumn{6}{|c|}{ 過酸化物 分解率 (\%) } \\
\hline & & \multicolumn{2}{|c|}{ サンマ油(1) } & \multicolumn{2}{|c|}{ サンマ油 (2) } & \multicolumn{2}{|c|}{ 大 豆 油 } \\
\hline & & $\begin{array}{l}\text { 無色 } \\
\text { ビン }\end{array}$ & $\mid \begin{array}{l}\text { カッ色 } \\
\text { ビン }\end{array}$ & $\begin{array}{l}\text { 無色 } \\
\text { ビン }\end{array}$ & $\begin{array}{l}\text { カッ色 } \\
\text { ビン }\end{array}$ & $\begin{array}{l}\text { 無色 } \\
\text { ビン }\end{array}$ & $\begin{array}{l}\text { カッ色 } \\
\text { ビン }\end{array}$ \\
\hline 1 & 5 & 19.8 & 10.5 & 17.5 & 2.3 & - & 一 \\
\hline 3 & 10 & - & - & - & - & 16.3 & $<1$ \\
\hline 4 & 15 & 36.2 & 18.9 & 33.4 & 16.6 & - & - \\
\hline 7 & 30 & 52.3 & 26.4 & 46.8 & 21.5 & 24.1 & 6.2 \\
\hline 10 & 40 & 62.6 & 28.9 & 52.2 & 25.7 & 30.7 & 8.2 \\
\hline 20 & 60 & 75.1 & 31.8 & 67.3 & 36.1 & 31.7 & 10.5 \\
\hline
\end{tabular}

備考 : 各試料油の実験開始前の過酸化物価はサンマ油 (1) 140 ，サンマ油 (2) 236, 大豆油 83.5 である。実 験は各試料全部飞わたって併列的飞行なったものでな く, 各試料ごとに無色ビン入りのものとカッ色ビン入り のものと併列的飞行なった。

\section{III. 総 括}

1. サンマ油, イワシ油, 鯨油, アマニ油, ゴマ油, トウモロコシ油, ツバキ油からの酸化油について $100^{\circ} \mathrm{C}$, 
$90^{\circ} \mathrm{C}, 50^{\circ} \mathrm{C}$ 扔よび室温活ける過酸化物の分解率を比 較してみると, 大体に和いて海産動物油過酸化物は植物 油過酸化物よりも分解率が大きい。植物油過酸化物の分 解率も試料どとに不同があって, 過酸化物価が同じ程度 の試料でも，酸化重合を起した変質程度の著しい植物油 の過酸化物は変質程度の少ない植物油の過酸化物より分 解しやすいようで岕る。植物油過酸化物の分解はサンマ 油からの高度不飽和酸メチルエステルを10\%添加する ことによって招招む社促進される傾向がある。

2. サンマ油から, 室温で暗所置いて酸化した試料, 日光暴露によって酸化した試料, $100^{\circ} \mathrm{C}$ 空気吹込みによっ て酸化した試料（各試料の過酸化物価はそれぞれ 50 付 近扔よび 150 付近）を製取して, $125^{\circ} \mathrm{C}, 100^{\circ} \mathrm{C}, 75^{\circ} \mathrm{C}, 50^{\circ} \mathrm{C}$ で過酸化物の分解率を比較してみると, 分解率は各試料 間に大差がない。しかし長期保存中に酸化して粘度の増 大した過酸化物価 393 の酸化サンマ油の過酸化物は上記 試料の過酸化物よりも大きい分解率を示した。

3. 酸化サンマ油に銅セッケン, 鉄セッケンなぞ酸化 促進剤を $0.2 \%$ 添加すると過酸化物の分解は著しく促進 される。NDGA，BHA，PG のような抗酸化剤を0.01〜 $0.06 \%$ 添加して子過酸化物の分解にはたいして影響しな い。また酸化促進剤と抗酸化剤を併用添加した場 合飞 は, 酸化促進剤の過酸化物分解促進作用はたいして抑制 されないようである。
4. 本実験の範囲内では, サンマ油過酸化物の分解反 応は二次反応上りはむしろ一次反応汇近いが，一次反応 によく一致する場合は少ない。

5. 日光照射はサンマ油㧍よび大豆油の過酸化物の分 解を促進する。

$$
\text { 文 昭和 } 33 \text { 年 } 5 \text { 月 } 28 \text { 日受理) }
$$

1）金田, 桜井, 石井, 日水誌, 20, 50 (1954)

2) 金田, 酒井, 石井, 日水誌, 20, 658 (1954)

3) N. Matsuo, J. Biochem. (Japan), 41, 481, 647 (1954)

4) 中村, 工化, 40, 494 (1937)

5) R.T. Holman, "Progress in the Chemistry of Fats and Other Lipids",Vol. 2, p. 77 (1954), London

6) O.S. Privett, W.O. Lundberg, Hormel Inst. Univ. Minn., Ann. Rept., 1950-51, p. 7

7) W.O. Lundberg, J. Am. Oil Chemists' Soc., 31, 523 (1954)

8) O.S. Privett, F.W. Quackenbush, J. Am. Oil Chemists' Soc., 31, 281 (1954)

9) P.M. Cooney, C.D. Evans, A.W. Schwab, J.C. Cowan, J. Am. Oil Chemists' Soc., 35, 152 (1958)

10) 下岡, 外山, 本誌, 7, 28 (1958)

11）下岡, 村瀬, 中神, 外山, 本誌, 6, 321 (1957)

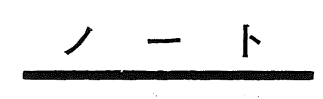

\section{綿実油, 米又力油の改質 \\ 竹下寿 雄* . 宮内徳之* \\ Modification of Cottonseed Oil and Rice Bran Oil}

Toshio Takeshita and Noriyuki Miyauchi

\section{1. 緒言}

半乾性油を改質して乾性油を製造するとは従来多くの 方法が発表されているが，大別するとつぎのようとな る。

（1）油飞他の物質を縮合または付加させる法：マレ イン化, スチレン化なぞ。

（2）脂肪酸部不飽和度向上法 : 飽和度の高いグリセ リドまたは脂肪酸を分別結晶なぞの物理的手段と，エス

* 鹿児島大学工学部応用化学教室（鹿児島市鴨池町） Department of Applied Chemistry, Faculty of Engineering, Kagoshima University
テル交換，尿素付加などの化学的手段を併用して除去す る。

（3）不飽和結合の共役化法：アルカリ，ニッケル， ヨウ化物，アントラキノン，亜硫酸ガスなぞとよる異性 化。

（4）再エステル化法：いった九油分子を分解し，グ リセリンよりも多価のアルコールを用いてふたたびエス テル化させる方法。

本邦産の代表的な半乾性油である米又カ油の改質飞つ いては, 従来種々の研究 ${ }^{1) \sim 4}$ が報告されて和り，また一 般飞半乾性油から乾性油の製造飞ついてもいくつかの報 交5 10$)$ が見受けられるが，著者らの研究によると飽和 